\title{
MODELING THEORY AND THE LEVEL OF MODEL COMPLEXITY
}

\author{
Lukáš Vogal $^{a}$, Miroslav Pecina $^{\mathrm{b}}$ \\ University of Defence in Brno, Department of Logistics, \\ Brno, Czech Republic, \\ a e-mail: lukas.vogal@unob.cz, \\ ORCID iD: (iohttp://orcid.org/0000-0002-3012-1693, \\ b e-mail: miroslav.pecina@unob.cz, \\ ORCID iD: Dhttp://orcid.org/0000-0002-7293-895X
}

DOI: 10.5937/vojtehg67-20537; https://doi.org/10.5937/vojtehg67-20537

FIELD: Logistics, Modeling

ARTICLE TYPE: Professional Paper

ARTICLE LANGUAGE: English

\section{Abstract:}

This article deals with the level of detail and complexity of the model. The aim of the article is to find out what are the objective options for determining the optimal level of detail and complexity of the model. First, the basic concepts of the model and modeling are explained. Consequently, the concepts of complexity and level of detail are examined. One of the solutions to this problem is a fictitious model and a theory of model performance measurement.

Key words: modeling, simulation, level of detail, complexity.

\section{Introduction}

The area of models and modeling is very broad. Models are used in many fields like industry, science, humanitarian help, etc. One of many model definitions (The Open University: OpenLearn, 2019) says that it is an abstraction which allows the observer to concentrate on the essentials of a (complex) problem by keeping out non-essential details. It also postulates that models are built in order to help in activities such as the development of large software systems. Models are less complicated than reality since they are simplifications of reality. Only the properties of the reality relevant to the modeler's main concern are represented. For example, a road map is a model of a particular part of the earth's surface. It does not show details such as vegetation or birds' nests as they are not relevant to the map purpose. The map should only contain the aspects of the real world that serve the purpose of planning journeys. 
Another author (Maria, 1997) defines a model as a representation of the construction and working of some system of interest. A model is similar to but simpler than the system it represents. One purpose of a model is to enable the analyst to predict the effect of changes to the system. A model should be, on the one hand, close to the real system. On the other hand, it should not be so complex that it is impossible to understand and experiment with it. In simple words, a good model is a judicious tradeoff between realism and simplicity. Simulation practitioners in general recommend increasing the complexity of a model iteratively. A model intended for a simulation study is a mathematical model developed with the help of simulation software. Mathematical model classifications include deterministic (input and output variables are fixed values) or stochastic (at least one of the input or output variables is probabilistic); static (time is not taken into account) or dynamic (timevarying interactions among variables are taken into account). Typically, simulation models are stochastic and dynamic (Maria, 1997).

Processes of building models can vary as there are many types of models. Its basic concept is usually similar, used by other authors as well, for instance (Brunclík, 2017).

It consists of several steps (Dlouhý, 2007):

1. Identification of examined problem and goal setting;

2. Building of a conceptual model;

3. Data collection;

4. Building of a simulation model;

5. Verification and validation;

6. Experiments and result analyses;

7. Documentation of a model; and

8. Implementation.

These steps are illustrated in Figure 1 bellow. 
Formulate a problem and plan the study

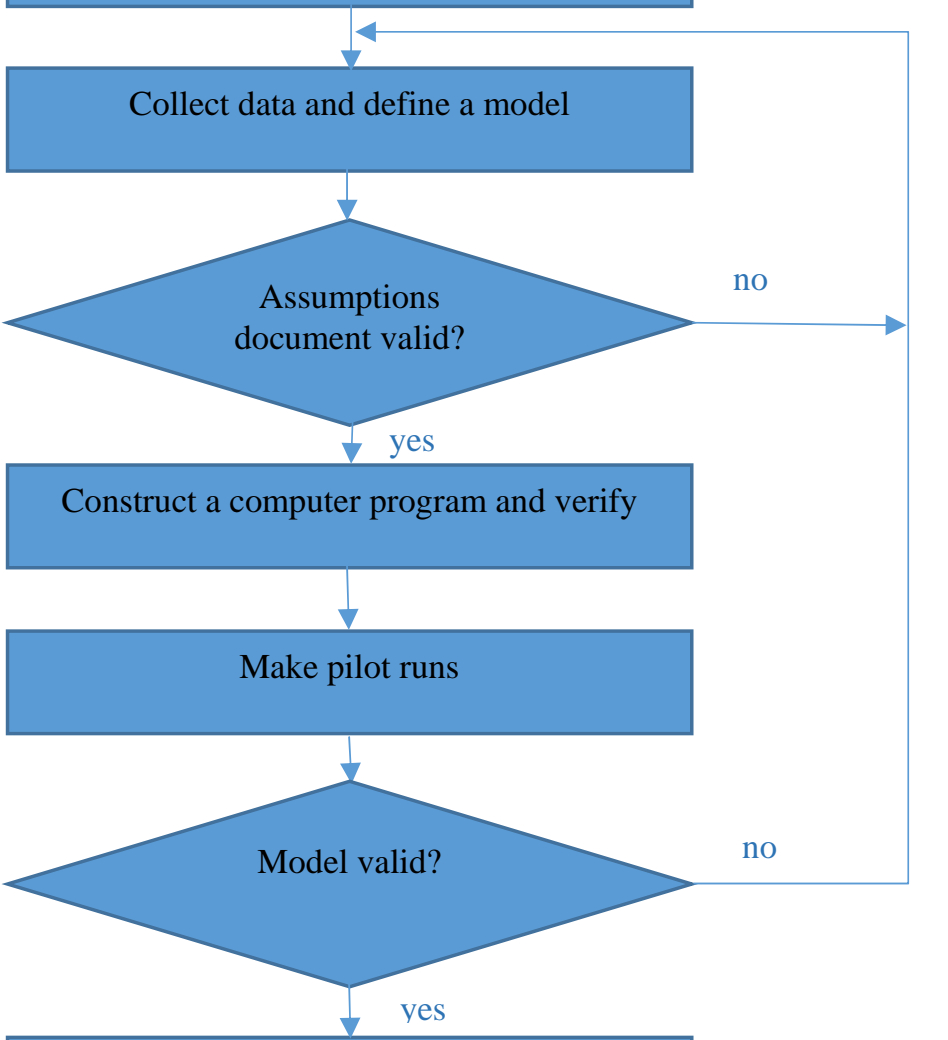

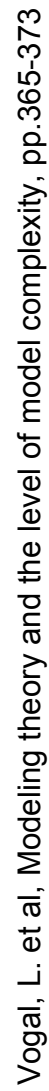

Design experiments

Make production runs

7

Analyze output data

Document, present, and use results

Figure 1 - Steps of modeling and a simulation of a model (Law, 2015)

Puc. 1 - Шаги в моделировании и симуляции модели (Law, 2015)

Слика 1 - Кораци у моделирању и симулацији модела (Law, 2015) 
As it was indicated above, during the modeling process, a question of model complexity/simplicity arises. Not even knowing the answer, the modeler solves this question in the step of conceptual model building. The goal of this step is to choose the best conceptual model which will lead to the best result of a project.

The conceptual model can be defined as a system representation created by the compositions of concepts that help people understand or simulate the entity that the model represents. The most widespread is the understanding of the model as something that in a certain sense represents another entity that, in the context of the model, is considered something to be imitated - modeled. There must be some kind of similarity between the model and the original for which the model is created. For example, by making it possible to consider from the results of the experiment with the model, what would be the results of the corresponding experiments performed on the original (Křemen, 2007)?

Choosing the best model is often a problem of selecting an appropriate level of detail or complexity, which is considered one of the most difficult aspects of the modeling process (Brooks \& Tobias, 1996). It is important to realize that the aspect of model complexity can decide about the project success. If a too high level of detail is chosen, the results are on the one hand precise and accurate. On the other hand, processing such a level of detail can be very expensive, so it takes much longer time to consider and measure so many data and finally the model also cannot be easily transformed for future use. The opposite situation would be if the model is too vague. Such a model could be easily transformed and used for a different situation. The problem is that the result of the model is too general and does not represent the specific reality to the desired extent.

\section{Level of detail and complexity}

Unfortunately, there is not one accepted definition of level of detail or complexity. However, in case we want to apply this term in the environment of the model and modeling, the level of detail could be understood as an extent of model's particularity. For instance, the extent of model elements, like the number of security scanners and guards in case of a model of the airport security check-in or the amount of cars, drivers, warehouses and customers in case of a distribution chain model.

Complexity, on the other hand, is used much more often in different kinds of the fields of science. For example, there is the mathematical 
complexity describing the difficulty in computing, software complexity, behavioral complexity, logical complexity and others.

Flood \& Carson (1993) see the complexity as anything that is hard to understand. Johnson (2001) says that complexity characterizes the behavior of a system or model whose components interact in multiple ways and follow local rules, meaning there is no reasonable higher instruction to define the various possible interactions.

Usually, the simple model is considered as the opposite to the complexity model.

As was mentioned above, the problem of choosing the best model or the best level of detail and complexity can also be easily imagined as the problem of selection the right one among many alternatives. Each of this alternatives has different specifics and would produce different performance in the project. Therefore, in order to select one alternative, each of them would have to be examined in terms of performance and compared.

Unfortunately, the research in this area is not sufficient. The possibilities of model performance measuring is examined in the next section.

\section{Model performance}

Brooks \& Tobias (1996), in their article Choosing the Best Model: Level of Detail, Complexity, and Model Performance postulate 11 steps, needed for proper measurement of model performance, divide them in 4 areas according to their role in a specific project. The word specific is, in this case, an important one. The model would provide different performances when applied for two different projects.

\section{Area of RESULTS}

1. The scope in which the model output describes the behavior of the examined object (adequacy of detail).

2. The accuracy of model results.

3. The simplicity with which the model and the results can be understood.

4. The area of the FUTURE USE OF THE MODEL

5. The portability of the model and the ease with which it can be combined with other models.

6. The area of VERIFICATION AND VALIDATION

7. The errors appearance probability (the created model does not correspond to the conceptual one) 
8. The accuracy with which the model corresponds to the historical data

9. The strength of the theoretical basis of the model including the quality of the input data (credibility of the model).

10. The area of the REQUIRED RESOURCES

11. The time and cost to build the model (data collection, verification, validation, etc.)

12. The time and cost to run the model

13. The time and cost to analyze the model results

14. The hardware requirements to run the model ( $p c$ memory, processor, etc.)

Assessing these steps in a model project and its alternatives could help to determine the level of detail and complexity appropriate to the model.

These steps can now be closely described using the example of the previously mentioned airport security check-in procedure.

\section{Model example}

Let the fictional check-in procedure be considered for a project of building one medium-sized airport. The problem of this part of the project is to buy a specific number of scanners, to hire a specific number of guards and to decide, consequently, how big this airport area should be. The goal of the model is therefore to determine the likely number of customers going through the security scanners per day.

Step 1 can be described as a scope in which the results of a model cover the experimental frame (Zeigler, 1976). It shows the level of detail of the model results. The following step 2 can simply be described in the following words: the more the results are accurate, the more the decisions taken and the conclusions drawn are likely to be correct. In the case of the airport project, it is desired that the result, the number of customers per day, is accurate in order to determine the optimum amount of all elements. However, it is not needed to know the exact number of customers for each day per year as there are some occasions like Christmas, New Year or Easter when the number would be much higher. These specific days only need to be considered as a deviation from the standard day.

If the project solver wants to be able to demonstrate the results of the model and the model itself properly, he/she needs to keep the model as simple as possible. This is how step 3 could be described. On the one 
hand, we want the model to be accurate; on the other hand, the more complicated the model is, the more likely some mistake in processing it can be made. Also, in many cases, the project owner is only the contracting authority and the model builder must subsequently present the results to them. It is not the part of their business to be able to understand specific scientific terms. Therefore, the builder should know to pay attention to this field as well.

Step 4 deals with the portability of the model. It means the possibility to transfer the model into a different system. In the case of the airport project, it means to take the model security check-in procedure and use it with different data. It might be important for a case when the project owner has two possible scenarios and is not sure about the concrete location of the airport. So, the model should be complex enough to enable the accurate results but also abstract enough to enable the portability between more system scenarios.

The scope of the level of detail used within the model may also correspond with the probability that the created model will not be the same as the conceptual model or that some input data will not be valid. The model must be trustworthy and all planned aspects in the conceptual model should be therefore included in the created model and stand on the true grounds. Also, is important that the model stays in the frame of historical data. Last but not least, the quality of the input data is also a very important factor. These points are considered in steps 5, 6 and 7 . By going through these steps, we can consider the extent of complexity of the model and the level of its detail in order to ensure the accurate results.

The last area of steps 8 to 11 estimates the resources needed to build the model. These steps consider the adequacy between the time and the costs spend for the model, the results it can bring and the level of detail and complexity which is incorporated in the model.

\section{Conclusion}

This area is not fully mapped, so it is not possible to determine unequivocally the optimal level of detail or complexity with which the model, or its results, should be processed. One option is outlined in the article along with a specific example of the model. There are 11 steps that model makers could use to have an overview of the significant points that should be particularly noticeable when designing and which can, at least partially, contribute to selecting the appropriate level of detail and complexity of the model. 


\section{References}

Brooks, R.J., \& Tobias, A.M. 1996. Choosing the best model: Level of detail, complexity, and model performance. Mathematical and Computer Modelling, 24(4), pp.1-14. Available at: https://doi.org/10.1016/08957177(96)00103-3.

Brunclík, M. 2017. Agend based modeling: when and how to create a succesful simulation. In: 12th PhD Conference Proceedings: New Approaches to the National Security, Brno: University of Defence in Brno, pp.93-98. February 14. ISBN 978-80-7231-402-7. Available at: https://www.unob.cz/fvl/vyzkum_vyvoj/Documents/Konference/Conference\%20P roceedings\%202017.pdf

Dlouhý, M. 2007. Simulace podnikových procesů.Brno: Computer Press (in Czech). ISBN 978-80-251-1649-4.

Flood, R.L., \& Carson, E.R. 1993. Dealing with Complexity: An Introduction to the Theory and Application of Systems Science.New York: Plenum Press. 2nd edition.

Johnson, S. 2001. Emergence: The Connected Lives of Ants, Brains, Cities.New York: Scribner, p.19. ISBN 978-3411040742.

Křemen, J. 2007. Modely a systémy Academia.Praha (in Czech).

Law, A.M. 2015. Simulation modeling and analysis.New York: McGraw-Hill Education. Fifth edition. ISBN 9781259254383.

Maria, A. 1997. Introduction to modeling and simulation. In S. Andradóttir, K.J. Healy, D.H. Withers, \& B.L. Nelson Eds., Proceedings of the 29th conference on Winter simulation - WSC '97, Atlanta, Georgia, USA, pp.7-13. December 07-10. Available at: https://doi.org/10.1145/268437.268440.

-The Open University: OpenLearn. 2019. Models and modelling. [Internet]. Available at: https://www.open.edu/openlearn/science-mathstechnology/computing-and-ict/models-and-modelling/content-section-2.1.

Accessed: 10 February 2019. Wiley.

Zeigler, B.P. 1976. Theory of Modelling and Simulation.New York: John

ТЕОРИЯ МОДЕЛИРОВАНИЯ И СЛОЖНОСТИ МОДЕЛЕЙ

Лукаш Вогал, Мирослав Пецина

Университет обороны в г. Брно, Отдел логистики,

г. Брно, Республика Чехия

РУБРИКИ: 81.88.00 Материально-техническое снабжение. Логистика, 28.17.31 Моделирование процессов управления

ВИД СТАТЬИ: профессиональная статья

ЯЗЫК СТАТЬИ: английский

Резюме:

В данной статье рассматриваются уровни детализации и сложности моделей, с целью выявления объективных 
вариантов определения оптимального уровня детализации и сложности моделей. В первой части статьи описаны основные концепции моделей и моделирования, а затем были представлены результаты испытаний концепции сложности и уровня детализации. В решении настоящей проблемы могут помочь воображаемая модель и теория оценки эфффективности модели.

Ключевые слова: моделирование, симуляция, уровень детализации, сложность.

\section{ТЕОРИЈА МОДЕЛОВАҢА И НИВО СЛОЖЕНОСТИ МОДЕЛА}

Лукаш Вогал, Мирослав Пецина

Универзитет одбране у Брну, Катедра логистике,

Брно, Чешка Република

ОБЛАСТ: логистика, моделовање

ВРСТА ЧЛАНКА: стручни рад

ЈЕЗИК ЧЛАНКА: енгЛесКИ

\section{Сажетак:}

У чланку се разматрају детаљи и сложеност модела, с циљем да се утврди које су објективне опције при одређивању њиховог оптималног нивоа. Објашњавају се основни концепти модела и моделовања, а затим се испитују концепти сложености и нивоа детаља. Једно од решења овог проблема представља замишљени модел, као и теорија мерења перформанси модела.

Кључне речи: моделовање, симулација, ниво детаља, сложеност.

Paper received on / Дата получения работы / Датум пријема чланка: 11.02.2019. Manuscript corrections submitted on / Дата получения исправленной версии работы / Датум достављања исправки рукописа: 25.02.2019.

Paper accepted for publishing on / Дата окончательного согласования работы / Датум коначног прихватања чланка за објављивање: 27.02.2019.

() 2019 The Authors. Published by Vojnotehnički glasnik / Military Technical Courier (www.vtg.mod.gov.rs, втг.мо.упр.срб). This article is an open access article distributed under the terms and conditions of the Creative Commons Attribution license (http://creativecommons.org/licenses/by/3.0/rs/).

() 2019 Авторы. Опубликовано в «Военно-технический вестник / Vojnotehnički glasnik / Military Technical Courier» (www.vtg.mod.gov.rs, втг.мо.упр.срб). Данная статья в открытом доступе и распространяется в соответствии с лицензией «Creative Commons» (http://creativecommons.org/licenses/by/3.0/rs/).

() 2019 Аутори. Објавио Војнотехнички гласник / Vojnotehnički glasnik / Military Technical Courier (www.vtg.mod.gov.rs, втг.мо.упр.срб). Ово је чланак отвореног приступа и дистрибуира се у складу са Creative Commons licencom (http://creativecommons.org/licenses/by/3.0/rs/). 